\title{
Prevalence and Determinants of Immediate and Long-Term PTSD Consequences of Coronavirus-Related (CoV-1 and CoV-2) Pandemics among Healthcare Professionals: A Systematic Review and Meta-Analysis
}

\author{
Buthaina al Falasi ${ }^{1,+}$, Mouza al Mazrouei ${ }^{1,+}$, Mai al Ali ${ }^{1,+}$, Maithah al Dham ani ${ }^{1}$, Aisha al Ali ${ }^{1}$, \\ Mariam al Kindi ${ }^{1}$, Murat Dalkilinc ${ }^{1}$, Mai al Qubaisi ${ }^{1}$, Luciana Aparecida Campos ${ }^{2,3,4}$, Hashel al Tunaiji 1,*, $\ddagger$ D \\ and Ovidiu Constantin Baltatu $3,4,5, *, \mp$ (D)
}

1 Zayed Military Hospital, Abu Dhabi P.O. Box 3740, United Arab Emirates; buthaina.alfalasi@gmail.com (B.a.F.); mouza.dr@gmail.com (M.a.M.); Mai.alali88@hotmail.com (M.a.A.); maithah.aldahmani@gmail.com (M.a.D.a.); maialali8891@gmail.com (A.a.A.); mariam.obaid.alkindi@gmail.com (M.a.K.); ptmurat@hotmail.com (M.D.); la2albi@hotmail.co.uk (M.a.Q.)

2 College of Health Sciences, Abu Dhabi University, Abu Dhabi P.O. Box 59911, United Arab Emirates; luciana.camposbalta@adu.ac.ae

check for updates

Citation: al Falasi, B.; al Mazrouei, M.; al Ali, M.; al Dhamani, M.; al Ali, A.; al Kindi, M.; Dalkilinc, M.; al Qubaisi, M.; Campos, L.A.; al Tunaiji, $\mathrm{H}$.; et al. Prevalence and Determinants of Immediate and Long-Term PTSD Consequences of Coronavirus-Related (CoV-1 and CoV-2) Pandemics among Healthcare Professionals: A Systematic Review and Meta-Analysis. Int. J. Environ. Res. Public Health 2021, 18, 2182. https://doi.org/10.3390/ijerph18042182

Academic Editor: Lucian-Ionel Cioca

Received: 18 January 2021

Accepted: 18 February 2021

Published: 23 February 2021

Publisher's Note: MDPI stays neutral with regard to jurisdictional claims in published maps and institutional affiliations.

Copyright: (c) 2021 by the authors. Licensee MDPI, Basel, Switzerland. This article is an open access article distributed under the terms and conditions of the Creative Commons Attribution (CC BY) license (https:// creativecommons.org/licenses/by/ $4.0 /)$.
3 Center of Innovation, Technology and Education (CITE) at Sao Jose dos Campos Technology Park, Sao Jose dos Campos 12247-016, Brazil

4 Institute of Biomedical Engineering, Anhembi Morumbi University-Laureate International Universities, Sao Jose dos Campos 12247-016, Brazil

5 College of Medicine and Health Sciences, Khalifa University, Abu Dhabi P.O. Box 127788, United Arab Emirates

* Correspondence: dr.hashel@gmail.com (H.a.T.); ovidiu.baltatu@ku.ac.ae (O.C.B.)

+ These authors contributed equally to this study.

$\ddagger \quad$ H.a.T. and O.C.B. should be considered joint senior author.

\begin{abstract}
Background: The COVID-19 pandemic continues to rise. In order to control the COVID-19 pandemic, healthcare professionals have been subjected to increased exposure to work stress. In this systematic review, we aimed at investigating the prevalence and determinants of immediate and long-term post-traumatic stress disorder (PTSD) effects on healthcare professionals by the COVID-19 (SARS CoV-2) and SARS-2003 (SARS CoV-1) pandemics. Methods: This systematic review was conducted according to the recommendations of the Protocols for Systemic Review and MetaAnalysis (PRISMA) statement. Only studies reporting the prevalence of PTSD (frequency, percentage) and related risk factors (adjusted odds ratio (OR)) in healthcare professionals (HCPs) during the SARS CoV-2 and SARS CoV-1 pandemics were included. The following databases were screened: Medline, Embase, PsychINFO, and Health Psychosocial Instrument (HaPI). Results: Six of eight studies reported PTSD symptoms among healthcare professionals during the COVID-19 pandemic in China (three), Singapore (one), India (one), and the United States of America (USA) (two), while two studies reported symptoms during the SARS-2003 pandemic in China (one) and Singapore (one). Sample sizes ranged from 263 to 5062 with a combined total of 10,074 participants. All of the studies self-reported the level of exposure to coronaviruses (CoV-1 and CoV-2) and severity of PTSD. Seven studies reported the prevalence of immediate PTSD and determinants, while one study reported delayed-onset PTSD (3 years after CoV-1 pandemic). Determinants of immediate PTSD were reported for the CoV-2 pandemic, while those for long-term PTSD were reported for the CoV-1 pandemic. Conclusions: A comprehensive understanding of the prevalence and determinants of immediate or long-term pandemic PTSD for healthcare workers can improve prevention, diagnosis, and management. Rigorous research measuring the prevalence of PTSD and its associated risk factors (adjusted OR) for the CoV-2 pandemic are envisaged. Although strategies to resolve immediate PTSD are key, long-term PTSD must not be overlooked.
\end{abstract}

Keywords: coronavirus; stress disorders; immediate and long-term PTSD; health personnel; risk factors; odds ratio 


\section{Introduction}

Early in December 2019, a newly discovered infectious coronavirus (CoV-2) disease occurred in Wuhan, Hubei Province, China [1]. The appearance of coronavirus CoV-2 did not prove to be an easy matter. The rapid global spread of the disease led to the declaration of a pandemic on 11 March 2020 [1]. It was subsequently termed Coronavirus Disease 2019 (COVID-19) [2]. The primary reported manifestation of COVID-19 is severe acute respiratory distress syndrome (SARS), ultimately leading to death in the most severe cases [3]. It was named CoV-2 since CoV-1 appeared as a pandemic in 2003 and caused a similar effect of SARS [1]. CoV-2 and CoV-1 share similarities at several levels. Both viruses have a high degree of homology and they share similar clinical features and disease dynamics [4]. The disease progression follows a similar trend for CoV-2 and CoV-1, with SARS occurring approximately 8-20 days after the first symptoms [5]. While this has yet to be confirmed, the two outbreaks appear to have a different epidemic trajectory. Whereas the SARS outbreak was brought under control in a matter of 8 months in 2003, the new pandemic in 2019 continues after more than a year. Although shorter in duration, the CoV-1 pandemic caused a great deal of distress not only in patients but also in healthcare professionals (HCPs), being named a "mental health catastrophe" [6]. Although both CoV-1 and CoV-2 pandemics resulted from coronaviruses, their impacts on healthcare professionals were different. Several determinants of occupational and psychosocial distress have been reported in HCPs during and after the CoV-1 pandemic, suggesting the need to establish strategies to help physicians through measures including timely knowledge sharing, effective infection control practices, income protection during outbreaks, and attention to family risk management [7]. Given the considerably higher severity of the CoV-2 compared to the $\mathrm{CoV}-1$ pandemic, lessons could be gained by evaluating the burdens of pandemics on HCP psychosocial distress, such as post-traumatic stress disorder (PTSD) [8]. Although the prevalence of PTSD in the CoV-2 pandemic can be predicted to be higher, common determinants of PTSD may be shared by both CoV-1 and CoV-2 pandemics.

The three hallmark features of a traumatic event as defined in DSM-5 (Diagnostic and Statistical Manual of Mental Disorders) are unpredictability, uncontrollability, and the threat of death or serious injury $[9,10]$. Pandemics, described as traumatic incidents, trigger a great deal of concern for HCPs and the health authorities. HCPs are passing through unprecedented challenges with the COVID-19 pandemic in many aspects. They are risking their own health and lives, threatened not only by exposure to the coronavirus but also by ever-increasing stress at the workplace, with amounts to a parallel the pandemic itself. Increased exposure to work-related stress has been associated with deleterious effects for mental health with higher rates of anxiety disorders. The recognition of early and long-term PTSD in healthcare professionals is becoming increasingly relevant for health policymakers to develop preventive measures to mitigate or avoid PTSD and related diseases. Dutheil et al. [1] described PTSD as the tsunami of the COVID-19 pandemic. PTSD is a severe mental health condition caused by an unusual traumatic life event beyond the normal range of human experience [11]. HCPs are under enormous pressure to manage this disaster, as they have to reorganize resources and the workforce to manage an unusual medical emergency. Being worried about their health, their families' health, contagion, and their colleagues' safety make them more prone to acute distress and potentially chronic PTSD $[1,3]$. Furthermore, the response by worldwide governments involving quarantine, social distance, lockdown measures, and media might contribute to PTSD [1,11,12]. We could, thus, overcome the pandemic, but then face a global public mental health crisis [13]. The pooled prevalence of PTSD symptoms among HCPs exposed to the COVID-19 pandemic ranged from $13 \%$ (95\% confidence interval (CI): $11 \%, 16 \%$ ) to $20.7 \%$ (95\% CI: $13.2 \%$, $31 \%)[14,15]$. Previous systematic and meta-analysis reviews on the COVID-19 pandemic reported combined odds ratios (ORs) of risk factors for mental disorders (anxiety, depression, occupational stress, PTSD, and insomnia) among HCPs [16,17]. However, to our 
knowledge, no systematic reviews investigated risk factors associated with immediate and long-term PTSD related to the SARS (CoV-1 and CoV-2) pandemics.

In this systematic review, we aimed at investigating the scientific evidence on immediate and long-term PTSD effects on healthcare professionals due to the COVID-2019 (SARS CoV-2) and SARS-2003 (SARS CoV-1) pandemics. We systematically reviewed the literature for the prevalence of PTSD symptoms and associated risk factors (adjusted OR) due to exposure to coronavirus pandemics COVID-2019 (SARS CoV-2) and SARS-2003 (SARS CoV-1) among healthcare professionals (HCPs).

\section{Methods}

This systematic review was conducted according to the recommendations of the Protocols for Systemic Review and Meta-Analysis (PRISMA) statement [18]. We included studies that focused on HCPs during pandemics COVID-2019 (SARS CoV-2) and SARS-2003 (SARS CoV-1). We narrowed our search to studies that focused on PTSD. The literature search was done on the following databases: Medline, Embase, PsychINFO, and Health Psychosocial Instrument (HaPI). The search was limited to primary studies published in peer-reviewed journals and in the English language from 1 January 2003 to 15 November 2020. As no cohort or case-control studies were found, only cross-sectional studies were included that reported prevalence of PTSD (frequency, \%) and associated risk factors (adjusted OR) using multivariate regression analysis. Qualitative interview-based studies, review articles, editorials, opinion or letter articles, and studies on students or trainees were excluded. The studies retrieved from the search were imported into Covidence ${ }^{\circledR}$. Covidence ${ }^{\circledR}$ is an online systematic review software management tool which allows uploading search results, screening abstracts and full-text study reports, completing data collection, conducting risk of bias assessment, and resolving disagreements (Covidence systematic review software, Veritas Health Innovation, Melbourne, Australia. Available at www.covidence.org, accessed on 22 February 2021). Duplicated papers were removed. Three groups consisting of two residents (B.a.F. and M.a.D., M.a.A. and M.a.M., and A.a.A. and M.a.K.) shared the systematic reviewing process equally and independently screened the title and abstract of each article according to their relevance. A second screening process was undertaken which involved reviewing the full text for each article to assess its eligibility. Any disagreement between the reviewing groups was resolved by three senior supervisory members M.D., M.a.Q., and H.a.T. Figure 1 shows study selection process. Data extraction was done by three investigators using a structured form. This included study information (author name, year of population, country, and study design), population (study sample, total number of participants, age, data collection time period, and follow-up period), exposure (definition, measurement, and categorization by degree of exposure), outcome (psychosocial outcomes, definitions, ascertainment, and classification by severity), confounders, point of prevalence estimate for outcomes (frequency, \%) exposure-outcome association measure (adjusted OR), and level of statistical significance ( $95 \%$ confidence intervals). As the studies included in this systematic review were all cross-sectional, the Joanna Briggs Institute Checklist for Analytical Approach for cross-sectional studies was used to assess their methodological quality [19]. 

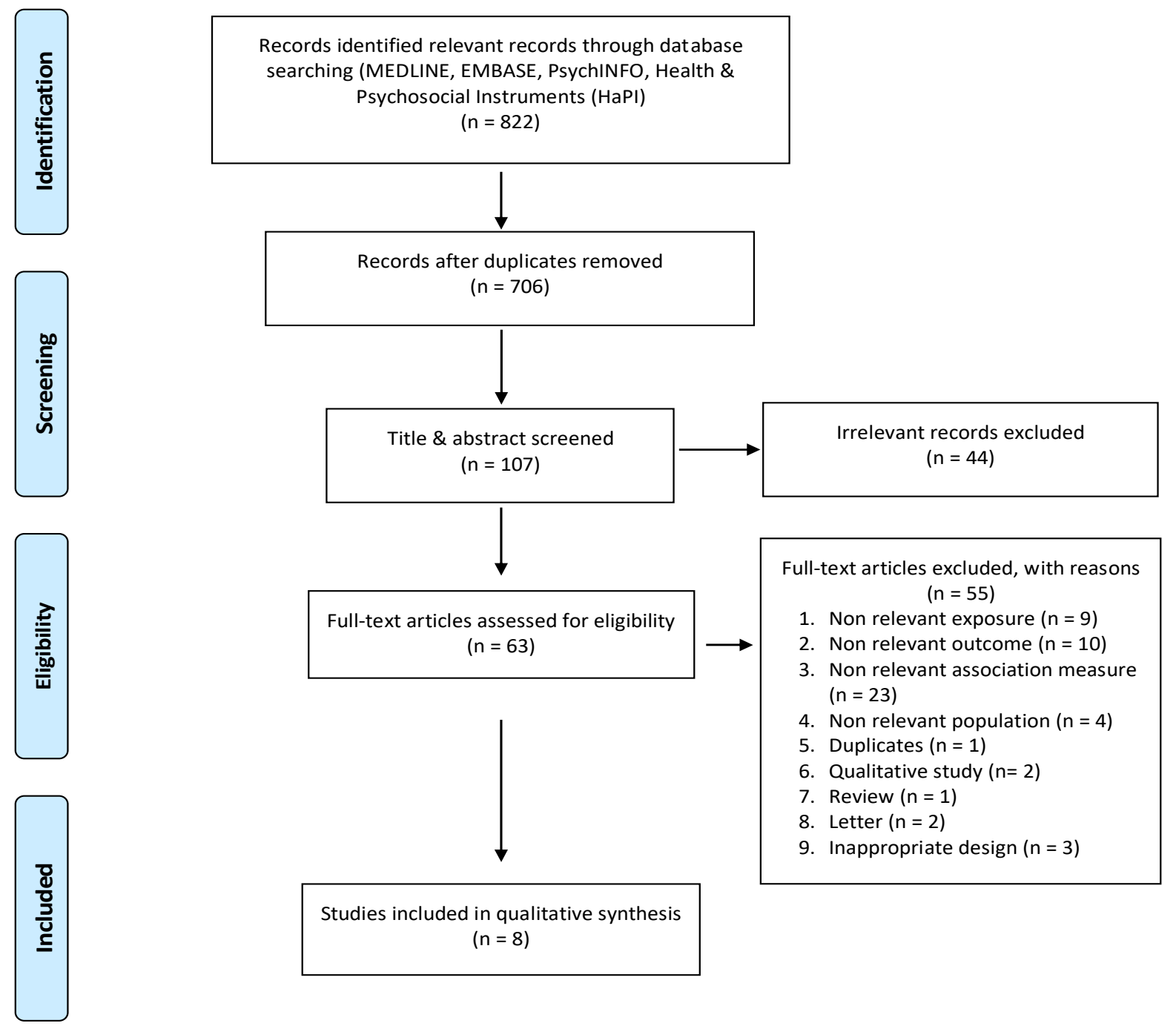

Figure 1. Flow diagram showing study selection for post-traumatic stress disorder (PTSD) related to coronavirus (CoV-1 and $\mathrm{CoV}-2$ ) pandemics among healthcare professionals (HCPs).

\section{Results}

The electronic search identified 822 candidate studies, 706 of which remained after the elimination of duplicates (Figure 1). A total of 599 publications were excluded, and 107 remained for title and abstract screening, of which 44 were excluded and 63 remained for full-text examination, of which 55 were excluded, as the goal was to include cross-sectional and cohort studies that reported the prevalence of PTDS and carried out a regression analysis of possible risk factors. The final search resulted in a total of eight studies enrolled in the qualitative synthesis. The eight studies were of cross-sectional design and are summarized by characteristics in Table 1, quality in Table 2, and estimates (prevalence and odds ratio) in Table 3 [3,20-26]. Six of the eight studies reported PTSD symptoms among healthcare professionals during the COVID-19 pandemic in Asia (China [20-22], Singapore [3], and India [3]) and North America (United States of America [23,24]), while two studies were undertaken during the SARS-2003 pandemic in Asia (China [25] and Singapore [26]). 


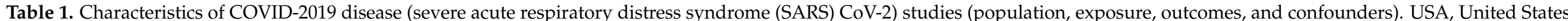
of America; PPE, personal protective equipment.

\begin{tabular}{|c|c|c|c|c|}
\hline $\begin{array}{l}\text { Author, Year, Country, } \\
\text { Study Design }\end{array}$ & $\begin{array}{l}\text { Population Study Sample, Total Number of Participants (Response Rate\%), } \\
\text { Sociodemographic Data, Data Collection Period }\end{array}$ & $\begin{array}{l}\text { Exposure Traumatic Event: Coronavirus (CoV-2) } \\
\text { Pandemic Definition, Measurement, Categorization }\end{array}$ & $\begin{array}{l}\text { Outcome Post-Traumatic Stress Disorder } \\
\text { (PTSD) Definition, Ascertainment } \\
\text { Classification }\end{array}$ & Confounders \\
\hline \multicolumn{5}{|c|}{ COVID-2019 Disease (SARS CoV-2) } \\
\hline $\begin{array}{l}\text { Zhu [21], 2020, China, } \\
\text { Cross-sectional }\end{array}$ & $\begin{array}{l}\text { - } 6568 \text { healthcare workers (HCW) in a single center, Tongji Hospital (Wuhan) were } \\
\text { surveyed. } \\
5281 \text { individuals completed the online questionnaire. } 5062 \mathrm{HCWs} \text { (all doctors, } \\
\text { nurses, and clinical technicians) were included in the final analysis (response rate, } \\
77.1 \% \text {. Administrates and incomplete questionnaires were excluded. } \\
\text { - The response rates of female and male HCWs were } 82.4 \% \text { and } 71.8 \% \text {. Most subjects } \\
\text { - were in the age intervals of } 19-29(40.1 \%) \text { and } 30-49 \text { years old }(56.4 \%) \text {. } \\
\text { Data collection period: } 8-10 \text { February } 2020,2 \text { weeks after transport suspension }\end{array}$ & $\begin{array}{l}\text { Definition: frontline HCWs directly in contact with } \\
\text { confirmed or suspected Covid-19 cases. } \\
\text { Measurement: self-reported frontline HCWs } \\
\text { working in isolation ward, fever clinic, or emergency } \\
\text { department. } \\
\text { Categorization: level of exposure classified by } \\
\text { current workplace (isolation ward, non-isolation } \\
\text { ward, off work or in isolation), department (fever } \\
\text { clinic, emergency department or isolation ward, } \\
\text { non-isolation ward, another department), present at } \\
\text { frontline (yes or no), COVID-19 infection status of } \\
\text { families or relatives or self-suspected or confirmed } \\
\text { (yes or no) }\end{array}$ & $\begin{array}{l}\text { Definition: acute psychological stress } \\
\text { Ascertainment: self-reported } 22 \text {-item } \\
\text { revised Impact Event Scale (IES-R) to assess } \\
\text { three subjective acute stress symptoms } \\
\text { (avoidance, intrusion, and hyperarousal) } \\
\text { caused by traumatic event. The IES-R was } \\
\text { validated in previous COVID-19 studies } \\
\text { which provided adequate specificity } \\
(91.0 \%) \text { and sensitivity }(82.0 \%) \text {. } \\
\text { Classification: IES-R scores (<33 or }>33 \text { ); } \\
\text { scores }>33 \text { points were used to identify } \\
\text { outcome of stress. }\end{array}$ & $\begin{array}{l}\text { Age, gender, } \\
\text { marital and social } \\
\text { status, education } \\
\text { level, occupation, } \\
\text { years of experience, } \\
\text { annual income, past } \\
\text { medical history, } \\
\text { smoking, drinking, } \\
\text { physical activity } \\
\text { level }\end{array}$ \\
\hline $\begin{array}{l}\text { Lai [20], 2020, China, } \\
\text { Cross-sectional }\end{array}$ & 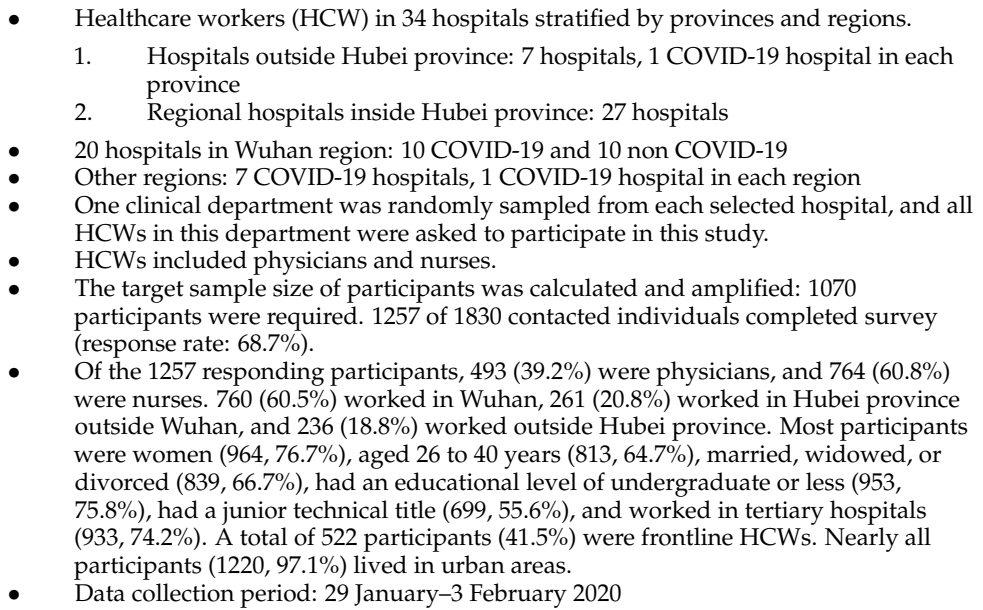 & $\begin{array}{l}\text { Definition: HCW in hospitals equipped with fever } \\
\text { clinics or wards for patients with COVID-19. } \\
\text { Measurement: self-reported exposure to COVID-19 } \\
\text { patients in fever clinics or wards during outbreak. } \\
\text { Categorization: level of exposure stratified by } \\
\text { - Geographical location: Wuhan, Hubei } \\
\text { province, outside Wuhan, or outside Hubei } \\
\text { province } \\
\text { Type of hospital: secondary or tertiary } \\
\text { Working position: frontline (directly engaged } \\
\text { in clinical activities of diagnosing, treating, or } \\
\text { providing nursing care to patients with } \\
\text { elevated temperature or patients with } \\
\text { confirmed COVID-19). If answered no, then } \\
\text { defined as second-line }\end{array}$ & $\begin{array}{l}\text { Definition: symptoms of distress } \\
\text { Ascertainment: self-reported 22-item } \\
\text { Impact of Event IES-R. } \\
\text { Classification: severity of symptoms } \\
\text { classified as normal (0-8), mild (9-25), } \\
\text { moderate ( } 26-43) \text {, and severe (44-88) } \\
\text { distress. Cutoff score > } 26 \text { for defined as } \\
\text { severe distress. }\end{array}$ & $\begin{array}{l}\text { Gender, age, marital } \\
\text { status, educational } \\
\text { level, technical title, } \\
\text { place of residence, } \\
\text { working position } \\
\text { (first-line or } \\
\text { second-line), and } \\
\text { type of hospital }\end{array}$ \\
\hline
\end{tabular}


Table 1. Cont.

\begin{tabular}{|c|c|c|c|c|}
\hline $\begin{array}{l}\text { Author, Year, } \\
\text { Country, Study } \\
\text { Design }\end{array}$ & $\begin{array}{c}\text { Population Study Sample, Total Number of Participants (Response Rate\%), } \\
\text { Sociodemographic Data, Data Collection Period }\end{array}$ & $\begin{array}{c}\text { Exposure Traumatic Event: Coronavirus } \\
\text { (CoV-2) Pandemic Definition, Measurement, } \\
\text { Categorization }\end{array}$ & $\begin{array}{l}\text { Outcome Post-Traumatic Stress } \\
\text { Disorder (PTSD) Definition, } \\
\text { Ascertainment Classification }\end{array}$ & Confounders \\
\hline $\begin{array}{l}\text { Nie }[22], 2020, \\
\text { China, } \\
\text { Cross-sectional }\end{array}$ & $\begin{array}{l}\text { - } 263 \text { nurses of the frontline department from seven designated hospitals for } \\
\text { COVID-19 patients in Guangdong Province participated in the survey } \\
\text { (response rate 30-40\%). } \\
\text { Of the } 263 \text { participants, } 202(76.7 \%) \text { were female and the majority }(n=236 \text {, } \\
89.7 \%) \text { were younger than } 39 \text { years of age. The most common }(n=189 \text {, } \\
71.9 \%) \text { educational qualification was undergraduate or above and the } \\
\text { majority }(n=196,74.5 \%) \text { worked in the emergency department. } \\
\text { Data collection period: } 3-11 \text { February } 2020\end{array}$ & $\begin{array}{l}\text { Definition: frontline nurses directly in contact } \\
\text { with infected or suspected COVID-19 patients. } \\
\text { Measurement: self-reported working on the } \\
\text { frontline department such as emergency } \\
\text { department, fever clinic, isolation ward, } \\
\text { intensive care unit (ICU), and infection } \\
\text { department. } \\
\text { Categorization: level of exposure classified } \\
\text { emergency department versus non-emergency } \\
\text { department }\end{array}$ & $\begin{array}{l}\text { Definition: symptoms of } \\
\text { post-traumatic stress disorder (PTSD). } \\
\text { Ascertainment: self-reported 22-item } \\
\text { revised Chinese version of the Impact } \\
\text { of Event Scale (IES-R) was used to } \\
\text { evaluate intrusive thoughts related to } \\
\text { COVID-19 and consequent avoidance } \\
\text { behavior. It was divided into three } \\
\text { dimensions: intrusion, avoidance, and } \\
\text { hyperarousal. } \\
\text { Classification: 4-point Likert scale } \\
\text { (scores 0-4) was adopted to assess the } \\
\text { IES in the past } 7 \text { days. Participants } \\
\text { with a score greater than or equal to } 20 \\
\text { were interpreted to be affected by } \\
\text { traumatic event. }\end{array}$ & $\begin{array}{l}\text { Gender, age, } \\
\text { educational level, } \\
\text { marital status, } \\
\text { working } \\
\text { department, } \\
\text { working years. }\end{array}$ \\
\hline $\begin{array}{l}\text { Chew [3], 2020, } \\
\text { Singapore and } \\
\text { India, } \\
\text { Cross-sectional }\end{array}$ & 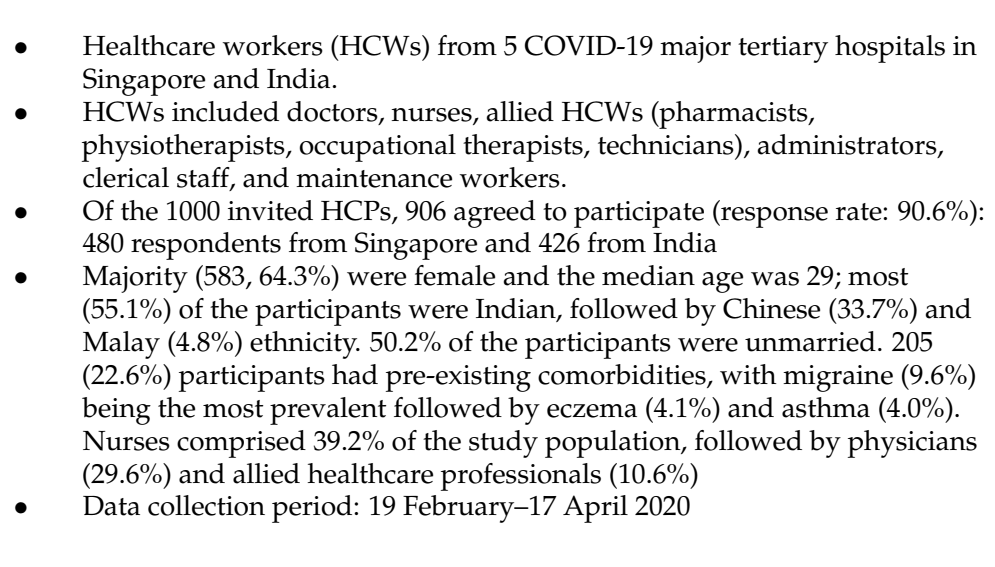 & $\begin{array}{l}\text { Definition: HCWs exposed to COVID-19 } \\
\text { patients. } \\
\text { Measurement: self-reported exposure to care } \\
\text { of COVID-19 patients in major tertiary } \\
\text { healthcare institutions during the outbreak. } \\
\text { Categorization: level of exposure not specified }\end{array}$ & $\begin{array}{l}\text { Definition: psychological } \\
\text { distress/impact during coronavirus } \\
\text { disease } 2019 \text { (COVID-19) outbreak. } \\
\text { Ascertainment: self-reported 22-item } \\
\text { Impact of Events Scale Revised } \\
\text { (IES-R25), divided in three subscales } \\
\text { (intrusion, avoidance, hyperarousal) } \\
\text { validated to measure subjective } \\
\text { distress symptoms during past } 7 \text { days } \\
\text { caused by traumatic event in Chinese } \\
\text { general population during COVID-19 } \\
\text { Classification: degree of severity } \\
\text { graded by IES-R25 score as normal } \\
\text { (0-23), mild (24-32), moderate (33-36), } \\
\text { or severe (>37). A cutoff score of } 24 \\
\text { used to define PTSD of clinical } \\
\text { concern. }\end{array}$ & $\begin{array}{l}\text { Age, gender, } \\
\text { presence of } \\
\text { comorbidities }\end{array}$ \\
\hline
\end{tabular}


Table 1. Cont.

\begin{tabular}{|c|c|c|c|c|}
\hline $\begin{array}{l}\text { Author, Year, Country, } \\
\text { Study Design }\end{array}$ & $\begin{array}{l}\text { Population Study Sample, Total Number of Participants (Response } \\
\text { Rate\%), Sociodemographic Data, Data Collection Period }\end{array}$ & $\begin{array}{l}\text { Exposure Traumatic Event: Coronavirus (CoV-2) Pandemic } \\
\text { Definition, Measurement, Categorization }\end{array}$ & $\begin{array}{l}\text { Outcome Post-Traumatic Stress Disorder } \\
\text { (PTSD) Definition, Ascertainment } \\
\text { Classification }\end{array}$ & Confounders \\
\hline $\begin{array}{l}\text { Arnetz [23], 2020, USA, } \\
\text { Cross-sectional }\end{array}$ & $\begin{array}{l}\text { Participants were recruited from the Michigan chapter of the } \\
\text { American Nurses Association (ANA), the Michigan Organization } \\
\text { of Nurse Leaders (MONL), and the Coalition of Michigan } \\
\text { Organizations of Nursing (COMON). All members of the three } \\
\text { organizations }(18,300) \text { and their colleagues were eligible. } \\
\text { Calculated sample size }(n=580) \text {. A total of } 695 \text { nurses responded } \\
\text { to the survey (response rate estimated at } 4 \%) \\
\text { Most of the respondents were female }(n=644,93.6 \%) \text {, older than } \\
45(n=376,54.7 \%) \text {, Caucasian }(n=611,87.9 \%), \text { and had been } \\
\text { working for more than } 10 \text { years }(n=449,67.1 \%) \text {. Majority } \\
(n=533,90.0 \%) \text { worked in urban locations, more than half } \\
\text { worked } 20-40 \mathrm{~h} \text { per week }(n=368,56.6 \%), \text { and } 36.6 \%(n=238) \\
\text { worked } 41-60 \mathrm{~h} \text { per week or more. Nearly } 60 \%(n=392,59.1 \%) \\
\text { worked in an inpatient setting and } 19.7 \%(n=135) \text { held a } \\
\text { management position. Forty percent }(n=269 ; 40.2 \%) \text { reported } \\
\text { being in frequent contact with COVID-19 patients while } 24.9 \% \\
(n=163) \text { reported not being provided with adequate PPE by their } \\
\text { workplace. } \\
\text { Data collection period: May } 2020\end{array}$ & $\begin{array}{l}\text { Definition: exposure to COVID-19 patients and access to } \\
\text { personal protective equipment (PPE). } \\
\text { Measurement: level of exposure by answering single-items } \\
\text { about frequency of contact with COVID-19 patients, access to } \\
\text { adequate PPE and number of hours worked per week, } \\
\text { practice setting, managerial position. } \\
\text { Categorization: } \\
\text { 1. Frequency of contact with COVID-19 patients: 4-point } \\
\text { response scale from never to very often. } \\
\text { 2. Access to adequate PPE: } 4 \text {-point scale from not at all to } \\
\text { definitely; not applicable could also be selected. } \\
\text { 3. Number of hours worked per week: }<20,20-40,41-60, \\
\text { 4. Practice setting: inpatient versus outpatient. } \\
\text { 5. Management position: yes or no }\end{array}$ & $\begin{array}{l}\text { Definition: symptoms of post-traumatic stress } \\
\text { disorder (PTSD). } \\
\text { Ascertainment: self-reported 6-item } \\
\text { Post-traumatic Checklist (PCL-6). An } \\
\text { abbreviated version of 20-item PTSD Checklist } \\
\text { screening for PTSD symptoms of "repeated, } \\
\text { disturbing memories, thoughts, or images of a } \\
\text { stressful experience from the past", "feeling } \\
\text { very upset when something reminded you of a } \\
\text { stressful experience from the past", avoided } \\
\text { activities or situations because they reminded } \\
\text { you of a stressful experience from the past, } \\
\text { feeling distant or cut off from other people, } \\
\text { feeling irritable or having angry outbursts, and } \\
\text { difficulty concentrating for the past } 4 \text { weeks. } \\
\text { Classification: severity of PTSD symptoms } \\
\text { rated on a scale from } 1 \text { (not at all) to } 5 \\
\text { (extremely). The cutoff score for presence of } \\
\text { PTSD symptoms was } 14 \text {. }\end{array}$ & $\begin{array}{l}\text { Age, gender, race, } \\
\text { number of hours } \\
\text { worked per week, } \\
\text { years, working as a } \\
\text { nurse, working in a } \\
\text { management position, } \\
\text { geographic location, } \\
\text { and work practice } \\
\text { setting (inpatient } \\
\text { versus outpatient/ } \\
\text { community) }\end{array}$ \\
\hline $\begin{array}{l}\text { Civantos [24], 2020, USA, } \\
\text { Cross-sectional }\end{array}$ & $\begin{array}{l}\text { A total of } 349 \text { otolaryngology physicians (residents, fellows, } \\
\text { attendings, and physicians) at the academic institutions across } \\
\text { the United States participated in the national survey. A total of } \\
1614 \text { otolaryngology residents and } 2849 \text { otolaryngology fellows } \\
\text { and attendings work was estimated (response rate was } 10.22 \%) \text {. } \\
\text { Of these, } 165(47.3 \%) \text { were residents, and } 184 \text { ( } 52.7 \%) \text { were } \\
\text { attending physicians, of which } 12 \text { were fellows. Most participants } \\
\text { were men }(212,60.7 \%) \text {, and the most common age range was } \\
31-35 \text { years }(114,32.7 \%) \text {. A number of } 126(36.1 \%) \text { participants } \\
\text { worked in the Midwest, } 107(30.7 \%) \text { worked in the Northeast, } 75 \\
(21.5 \%) \text { worked in the South, and } 41 \text { (11.7\%) worked in the West. } \\
\text { The majority came from states projected to reach their peak } \\
\text { resource use during the study period (205, 58.7\%). Accordingly, } \\
54.2 \% \text { of participants came from states estimated to have greater } \\
\text { than } 20 \text { o00 confirmed positive COVID-19 cases, and } 54.2 \% \text { came } \\
\text { from states estimated to have greater than } 1000 \text { COVID-19 deaths. } \\
\text { Data collection period: } 14 \text { April } 2020 \text { to } 25 \text { April } 2020 \text {. }\end{array}$ & $\begin{array}{l}\text { Definition: peak of resource utilization for each state during } \\
\text { COVID-19 outbreak. } \\
\text { Measurement: Date of projected peak resource utilization } \\
\text { Institute for Health Metrics and Evaluation's COVID-19 } \\
\text { Projections. } \\
\text { Categorization: level of participants' exposure was } \\
\text { categorized by state's surge status into pre-surge, surge, and } \\
\text { post-surge on the basis of number of positive COVID-19 cases } \\
\text { (< or }>20,000) \text { and COVID-19 deaths }(<\text { or }>1000) \text { published on } \\
\text { Institute for Health Metrics and Evaluation's Covid-19 } \\
\text { Projections. }\end{array}$ & $\begin{array}{l}\text { Definition: psychological distress (PTSD) } \\
\text { symptoms } \\
\text { Ascertainment: self-reported 15-item Impact of } \\
\text { Event Scale (IES, score range: } 0-75 \text { ) to assess } \\
\text { symptoms of PTSD over the past } 7 \text { days. The } \\
\text { IES total score was also divided into two sub } \\
\text { scores: intrusion (range: } 0-35 \text { ) and avoidance } \\
\text { (range: } 0-40) \text {. } \\
\text { Classification: severity of PTSD symptoms was } \\
\text { classified as subclinical (0-8), mild (9-25), } \\
\text { moderate ( } 26-43 \text { ), and severe ( } 44-75 \text { ) distress. A } \\
\text { score of } 27 \text { was reported as a cutoff for risk of } \\
\text { post-traumatic stress disorder (PTSD). }\end{array}$ & $\begin{array}{l}\text { Type of physician, sex, } \\
\text { age, surge status, and } \\
\text { number of positive } \\
\text { cases }\end{array}$ \\
\hline
\end{tabular}


Table 1. Cont.

\begin{tabular}{|c|c|c|c|c|}
\hline $\begin{array}{l}\text { Author, Year, Country, } \\
\text { Study Design }\end{array}$ & $\begin{array}{l}\text { Population Study Sample, Total Number of Participants (Response } \\
\text { Rate\%), Sociodemographic Data, Data Collection Period }\end{array}$ & $\begin{array}{l}\text { Exposure Traumatic Event: Coronavirus (CoV-2) Pandemic } \\
\text { Definition, Measurement, Categorization }\end{array}$ & $\begin{array}{l}\text { Outcome Post-Traumatic Stress Disorder } \\
\text { (PTSD) Definition, Ascertainment } \\
\text { Classification }\end{array}$ & Confounders \\
\hline \multicolumn{5}{|c|}{ SARS-2003 (SARS CoV-1) } \\
\hline $\begin{array}{l}\text { Wu [25], 2009, China, } \\
\text { Cross-sectional }\end{array}$ & $\begin{array}{l}\text { - Healthcare workers (HCWs) from a major hospital in Beijing that } \\
\text { had been affected by the } 2003 \text { SARS outbreak } \\
549 \text { HCWs participated and were stratified by } 3 \text { professional } \\
\text { categories: doctor, nurse, and administrative and/or other } \\
\text { hospital staff (response rate } 83 \% \text { ). } \\
\text { - Three-fourths of the sample were women; } 47 \% \text { were aged } \\
\text { between } 36 \text { and } 50 \text { years; } 19 \% \text { were aged } 50 \text { years or older } \\
\text { - Data collection period (2006, 3 years post SARS-2003 outbreak) }\end{array}$ & $\begin{array}{l}\text { Definitions: exposure to SARS outbreak as a traumatic event } \\
\text { related to work, any quarantining, having a friend or close } \\
\text { relative who contracted SARS, media, and other traumatic } \\
\text { events. } \\
\text { Measurement: self-reported profession (doctor, nurse, } \\
\text { technician, others), work exposure (working in a high-risk } \\
\text { location, such as a SARS ward, fever clinic, infectious disease } \\
\text { department, emergency room, pulmonary medicine } \\
\text { department, or X-ray laboratory), quarantine (as a result of } \\
\text { being diagnosed with SARS or suspected of having SARS, or } \\
\text { as having had direct contact with SARS patients either at } \\
\text { work, at home, or in other places), relative or friend got SARS } \\
\text { (having one or more family members or friends who } \\
\text { developed SARS, and either died from or recovered from it), } \\
\text { media (amounts of exposure to coverage about the SARS } \\
\text { outbreak the hospital employees had received, through } 3 \\
\text { types of media: television, websites, and other (radio, } \\
\text { newspapers, or magazines)), and other traumatic events (any } \\
\text { potentially traumatic event prior to and following the } \\
\text { SARS-2003 outbreak (severe injury in violent circumstances, } \\
\text { witnessing a death or serious injury of a close friend or family } \\
\text { member, and living through a major disaster). } \\
\text { Categorization: level of exposure for doctor and nurse was } \\
\text { classified as either high (who worked in units such as SARS } \\
\text { wards, fever clinics, the department of infectious diseases, or } \\
\text { the emergency room, where contact with SARS patients was } \\
\text { frequent and intense) or low. }\end{array}$ & $\begin{array}{l}\text { Definition: persistence of post-traumatic stress } \\
\text { disorder (PTSD) symptoms } 3 \text { years post } \\
\text { Beijing's SARS-2003 outbreak } \\
\text { Ascertainment: self-reported } 22 \text {-item Impact of } \\
\text { Events Scale Revised (IES-R) that was translated } \\
\text { and validated in Chinese to assess subjective } \\
\text { distress symptoms resulting from a traumatic } \\
\text { life event persisting over the past month. } \\
\text { Classification: Likert rating pcale from } 0 \text { to } 4 \text {; } \\
\text { the total score had a range of } 0 \text { to } 88 \text {. Score of } 20 \\
\text { or more indicated high level of PTSD symptoms }\end{array}$ & $\begin{array}{l}\text { Sociodemographic } \\
\text { variables (age, gender, } \\
\text { family income, } \\
\text { educational level), } \\
\text { prior exposure to } \\
\text { trauma, perceived risk } \\
\text { during the SARS } \\
\text { outbreak, altruistic } \\
\text { acceptance of risk }\end{array}$ \\
\hline $\begin{array}{l}\text { Chan [26], 2004, } \\
\text { Singapore, } \\
\text { Cross-sectional }\end{array}$ & 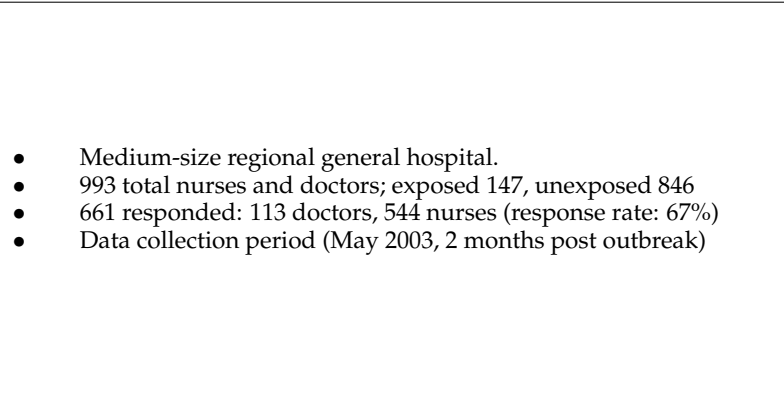 & $\begin{array}{l}\text { Definition: exposure or SARS in a regional hospital } 2 \text { months } \\
\text { after the first case of SARS was reported. } \\
\text { Measurement: self-reported exposure of being contact with } \\
\text { suspect or probable SARS patients (yes, no or not sure), } \\
\text { workplace (intensive care unit, emergency department, fever } \\
\text { ward, general, others) } \\
\text { Categorization: sample classified into } 2 \text { groups on the basis of } \\
\text { level of exposure } \\
\text { Group A: HCWs who were first-generation contacts or who } \\
\text { had direct contact with suspect or probable SARS patients } \\
\text { (total: } 106 \text {, doctors: } 32 \text {, nurses: } 74 \text { ) } \\
\text { Group B: HCWs who did not have direct contact with any } \\
\text { suspect or probable SARS patients (total: 555, doctors: } 81 \\
\text { nurses: } 474 \text { ) }\end{array}$ & $\begin{array}{l}\text { Definition: Post-traumatic stress disorder } \\
\text { (PTSD) symptoms among HCWs exposed to } \\
\text { SARS outbreak. } \\
\text { Ascertainment: self-reported } 15 \text {-item Impact of } \\
\text { Events Scale (IES-15) to assess PTSD symptoms. } \\
\text { Classification: PTSD present or absent; IES } \\
\text { score > } 30 \text { was chosen for indicating presence. }\end{array}$ & $\begin{array}{l}\text { Age, race, marital } \\
\text { status, and workplace }\end{array}$ \\
\hline
\end{tabular}


Table 2. Quality assessment of included studies.

\begin{tabular}{|c|c|c|c|c|c|c|c|c|c|}
\hline Author, Year & 1 & 2 & 3 & 4 & 5 & 6 & 7 & 8 & Total $(/ 8)$ \\
\hline \multicolumn{10}{|c|}{$\begin{array}{l}\text { COVID-2019 disease } \\
\text { (SARS CoV-2) }\end{array}$} \\
\hline Zhu [21] & $\mathrm{Y}$ & $\mathrm{Y}$ & $\mathrm{Y}$ & $\mathrm{N}$ & $\mathrm{Y}$ & $\mathrm{Y}$ & $\mathrm{N}$ & $\mathrm{Y}$ & 6 \\
\hline Lai [20] & $\mathrm{Y}$ & $\mathrm{Y}$ & $\mathrm{Y}$ & $\mathrm{N}$ & $\mathrm{Y}$ & $\mathrm{Y}$ & $\mathrm{Y}$ & $\mathrm{Y}$ & 7 \\
\hline Nie [22] & $\mathrm{Y}$ & $\mathrm{Y}$ & $\mathrm{N}$ & $\mathrm{N}$ & $\mathrm{Y}$ & $\mathrm{Y}$ & $\mathrm{N}$ & $\mathrm{Y}$ & 5 \\
\hline Chew [3] & $\mathrm{Y}$ & $\mathrm{Y}$ & $\mathrm{N}$ & $\mathrm{N}$ & $\mathrm{Y}$ & $\mathrm{Y}$ & $\mathrm{Y}$ & $\mathrm{Y}$ & 6 \\
\hline Arnetz [23] & $\mathrm{Y}$ & $\mathrm{Y}$ & $\mathrm{Y}$ & $\mathrm{N}$ & $\mathrm{Y}$ & $\mathrm{Y}$ & $\mathrm{N}$ & $\mathrm{Y}$ & 6 \\
\hline Civantos [24] & $\mathrm{Y}$ & $\mathrm{Y}$ & $\mathrm{N}$ & $\mathrm{N}$ & $\mathrm{Y}$ & $\mathrm{Y}$ & $\mathrm{Y}$ & $\mathrm{Y}$ & 6 \\
\hline \multicolumn{10}{|c|}{ SARS-2003 (SARS } \\
\hline $\mathrm{Wu}[25]$ & $\mathrm{Y}$ & Y & $\mathrm{Y}$ & $\mathrm{N}$ & $\mathrm{Y}$ & $\mathrm{Y}$ & $\mathrm{N}$ & $\mathrm{Y}$ & 6 \\
\hline Chan [26] & $\mathrm{Y}$ & $\mathrm{Y}$ & $\mathrm{Y}$ & $\mathrm{N}$ & $\mathrm{Y}$ & $\mathrm{Y}$ & $\mathrm{N}$ & $\mathrm{Y}$ & 6 \\
\hline
\end{tabular}

1. Were the criteria for inclusion in the sample clearly defined? 2. Were the study subjects and the setting described in detail? 3. Was the exposure measured in a valid and reliable way? 4. Were objective, standard criteria used for measurement of the condition? 5 . Were confounding factors identified? 6. Were strategies to deal with confounding factors stated? 7. Were the outcomes measured in a valid and reliable way? 8. Was appropriate statistical analysis used? Y: yes, N: no, NA: not available.

Table 3. Summary of studies that reported prevalence (frequency, \%), severity, and factors significantly associated with post-traumatic stress disorder (PTSD) symptoms following multivariable logistic regression for COVID-19 disease (SARS CoV-2) and SARS-2003 (SARS CoV-1).

\begin{tabular}{|c|c|c|}
\hline $\begin{array}{l}\text { Publication } \\
\text { (Author, Year, } \\
\text { Country) }\end{array}$ & $\begin{array}{c}\text { Outcome } \\
\text { PTSD Symptoms (Frequency, \%) } \\
\text { Severity Categories of Traumatic Stress Symptoms }\end{array}$ & $\begin{array}{l}\text { Association Measure: Odds Ratio (OR), 95\% } \\
\text { Confidence Interval (CI) } \\
\text { Factors Significantly Associated with PTSD }\end{array}$ \\
\hline \multicolumn{3}{|c|}{ COVID-2019 Disease (SARS CoV-2) } \\
\hline $\begin{array}{c}\text { Zhu [21], 2020, } \\
\text { China }\end{array}$ & $\begin{array}{c}\text { Study sample size } \\
n=5062 \\
\text { Overall prevalence of PTSD symptoms } \\
\text { IES-R22 cutoff score }>33 \text { for detecting symptoms, past } 7 \text { days } \\
1506 / 5062(29.8 \%) \\
\text { Severity categories of traumatic stress symptoms } \\
\text { Not reported }\end{array}$ & $\begin{array}{c}\text { Gender } \\
\text { Female: } 1.31(1.02,1.66) \\
\text { Education level } \\
\text { Master's degree or higher: } 1.55(1.16,2.07) \\
\text { Occupation } \\
\text { Nurse: } 2.24(1.61,3.12) \\
\text { Medical technician: } 1.57(1.12,2.21) \\
\text { Years of working } \\
\text { 6-10 years: } 1.71(1.25,2.30) \\
\text { >10 years: } 2.02(1.47,2.79) \\
\text { Department/ working position } \\
\text { Isolation ward: } 1.32(1.10,1.59) \\
\text { Past medical history } \\
\text { Positive for chronic disease: } 1.51(1.27,1.80) \\
\text { Positive for mental disorder: } 3.27(1.77,6.05) \\
\text { Social status } \\
\text { Living with family members: } 1.18(1.01,1.38) \\
\text { Family members or relatives suspected or } \\
\text { confirmed COVID-19 case: } 1.23(1.02,1.48) \\
\text { Parenteral status } \\
\text { Two or more children: } 1.56(1.22,1.99)\end{array}$ \\
\hline $\begin{array}{c}\text { Lai [20], 2020, } \\
\text { China }\end{array}$ & $\begin{array}{c}\text { Study sample size } \\
n=1257 \\
\text { Overall prevalence of PTSD symptoms } \\
\text { IES-R22 cutoff score }>26 \text { for detecting "severe" symptoms, past } 7 \text { days } \\
899 / 1257(71.5 \%) \\
\text { Severity categories of traumatic stress symptoms } \\
\text { Normal (0-8): } 358 / 1257(28.5 \%) \\
\text { Mild (9-25): } 459 / 1257(36.5 \%) \\
\text { Moderate }(26-43): 308 / 1257(24.5 \%) \\
\text { Severe }(44-88): 132 / 1257(10.5 \%)\end{array}$ & $\begin{array}{c}\text { Gender } \\
\text { Female: } 1.45(1.08-1.96) \\
\text { Working years/Technical title } \\
\text { Intermediate: } 1.94(1.48,2.55) \\
\text { Department/working position } \\
\text { Frontline: } 1.60(1.25,2.04) \\
\text { Geographical location } \\
\text { Outside Hubei province: } 0.62(0.43,0.88)\end{array}$ \\
\hline $\begin{array}{c}\text { Nie [22], 2020, } \\
\text { China }\end{array}$ & $\begin{array}{c}\text { Study sample size } \\
n=263 \\
\text { Overall prevalence of PTSD symptoms } \\
\text { IES-R22 cutoff score }>20 \text { for detecting symptoms, past } 7 \text { days } \\
66 / 263(25.1 \%) \\
\text { Severity categories of traumatic stress symptoms } \\
\text { Not reported }\end{array}$ & $\begin{array}{l}\text { Working years }(>4 \text { years }) \\
1.53(1.12,2.10) \\
\text { Concern of own } \\
4.48(2.38,8.42) \\
\text { Negative coping style } \\
5.40(2.54,11.46) \\
\text { Positive coping style } \\
0.38(0.22,0.67)\end{array}$ \\
\hline
\end{tabular}


Table 3. Cont.

\begin{tabular}{|c|c|c|}
\hline $\begin{array}{l}\text { Publication } \\
\text { (Author, Year, } \\
\text { Country) }\end{array}$ & $\begin{array}{c}\text { Outcome } \\
\text { PTSD Symptoms (Frequency, \%) } \\
\text { Severity Categories of Traumatic Stress Symptoms }\end{array}$ & $\begin{array}{l}\text { Association Measure: Odds Ratio (OR), 95\% } \\
\text { Confidence Interval (CI) } \\
\text { Factors Significantly Associated with PTSD }\end{array}$ \\
\hline \multicolumn{3}{|c|}{ COVID-2019 Disease (SARS CoV-2) } \\
\hline $\begin{array}{c}\text { Civantos [24] } \\
\text { 2020, USA }\end{array}$ & $\begin{array}{c}\text { Study sample size } \\
n=349 \\
\text { Overall prevalence of PTSD symptoms } \\
\text { IES-R15 cutoff score }>27 \text { for detecting symptoms, past } 7 \text { days } \\
210 / 349=60.2 \% \\
\text { Severity categories of traumatic stress symptoms } \\
\text { Subclinical }(0-8): 139 / 349(39.8 \%) \\
\text { Mild }(9-25): 114 / 349(32.7 \%) \\
\text { Moderate }(26-43): 73 / 349(20.9 \%) \\
\text { Severe }(44-75): 23 / 349(6.6 \%)\end{array}$ & $\begin{array}{c}\text { Gender } \\
\text { Female: } 2.68(1.64,4.37) \\
\text { Covid-19 positive cases } \\
>20,000 \text { cases: } 2.01(1.22,3.31)\end{array}$ \\
\hline
\end{tabular}

\section{SARS-2003 (SARS CoV-1)}

\begin{tabular}{|c|c|c|}
\hline $\begin{array}{c}\text { Chan [26], 2004, } \\
\text { Singapore }\end{array}$ & $\begin{array}{c}\text { Study sample size } \\
n=661 \\
\text { Overall prevalence of PTSD symptoms } \\
\text { IES-R15 cutoff score }>30 \text { for detecting presence of PTSD, past } 7 \text { days } \\
20 / 661(3 \%) \\
\text { Doctors }(n=6) \\
6 / 906(0.9 \%) \\
\text { Nurses }(n=14) \\
14 / 906(2.1 \%) \\
\text { Severity categories of traumatic stress symptoms } \\
\text { Noted reported }\end{array}$ & $\begin{array}{c}\text { Life priorities factors } \\
0.88(0.51,1.54) \text {, statistically not significant } \\
\text { Coping factors } \\
0.92(0.53,1.61) \text {, statistically not significant }\end{array}$ \\
\hline $\begin{array}{c}\text { Wu [25], 2009, } \\
\text { China (past } \\
3 \text { years) }\end{array}$ & $\begin{array}{c}\text { Study sample size } \\
n=549 \\
\text { Overall prevalence of delayed or persistent PTSD symptoms (3 years post } \\
\text { SARS) } \\
\text { IES-R22 cutoff score }>20 \text { for detecting high level symptoms, past } 4 \text { weeks } \\
55 / 549=10 \% \\
\text { Severity categories of traumatic stress symptoms } \\
\text { Not reported }\end{array}$ & $\begin{array}{l}\text { Age } \\
<35 \text { years: } 5.08(1.5-17.7) \\
\text { 36-50 years: } 4.54(1.3-15.6) \\
\text { High work exposure } \\
3.11(1.8-5.5) \\
\text { Any quarantine } \\
\text { 3.47 (1.9-6.2) } \\
\text { Relative or friend got SARS } \\
\text { 3.74 (1.8-7.6) }\end{array}$ \\
\hline
\end{tabular}

PCL-6: 6-item post-traumatic checklist; IES: impact of event scale.

Sample size ranged from 263 to 5062 with a combined total of 10,074 participants. All of the studies self-reported level of exposure to coronaviruses (CoV-1 or CoV-2) and severity of PTSD symptoms using paper or online surveys with a response rate above $80 \%[3,25]$, of $60-80 \%[20-22,26]$, and below $15 \%$ [23,24]. Three studies were conducted in a single hospital $[21,25,26]$, three studies were conducted in multiple hospitals [3,20,22], one study was conducted in a single state [23], and two studies were conducted in multiple states or provinces $[20,24]$. Two studies were investigated merely nursing staff $[22,23]$, one study had a majority of female nursing staff $(93.6 \%)$ [23], one study recruited just otolaryngology physicians [24], and two studies focused on nurses and doctors [20,26]. Three studies included allied HCPs and administrates [3,21,25]. All studies reported prevalence of acute or immediate PTSD symptoms during or immediately after the pandemic except one study [25] which reported delayed-onset or long-term PTSD (3 years after SARS-2003 pandemic). Evidently, to date, there is no study reporting long-term PTSD after CoV-2 pandemic.

All studies specified and categorized level of exposure with slight variations except one study [3] which did not report how the level of exposure was categorized. All studies used the Impact Event Scale (IES, 22-items, [3,20-22,25] and 15-items, [24,26]) with different cutoff scores to detect PTSD symptoms and their severity in the past 7 days except one study [25] which evaluated the past 4 weeks 3 years post SARS-2003 outbreak, whereas another study [23] used the six-item Post-Traumatic Checklist (PCL-6) in the past 4 weeks. All studies used logistic regression model to control and adjust for different risk factors and confounders. 


\subsection{Quality Assessment}

Total quality scores for methodology were seven [20], six [3,21,23-25], and five [22] out of eight on the Joanna Briggs Institute Checklist for Analytical Approach for cross-sectional studies. None of studies used objective measurements or clinical interviews for PTSD symptoms (Table 2).

\subsection{Prevalence and Determinants of Acute PTSD Symptoms}

Regarding SARS CoV-1, the prevalence estimate of acute PTSD symptoms for Singapore was 3\% [26].

Regarding SARS CoV-2, the prevalence of acute PTSD symptoms ranged between $25.1 \%$ and $71.5 \%$ for China [20-22] among HCPs, was $4 \%$ for Singapore [3], was $3.4 \%$ for India [3], and ranged between $26.5 \%$ and $60.2 \%$ for USA [23,24].

\subsection{Determinants of Acute or Immediate PTSD}

The following variables have been shown by multivariable logistics regressive research to correlate with a higher risk of acute PTSD symptoms (Figure 2): age ( $<45$ years old), OR 1.67 (95\% CI: 1.14, 2.44) [23], female, OR between 1.31 (95\% CI: 1.02, 1.66) [21] and 2.68 $(1.64,4.37)$ [24], working experience $>4$ years, OR between 1.53 (95\% CI: 1.12, 2.10) [22] and $>10$ years, OR 2.02 (95\% CI: 1.47, 2.79) [21], frontline HCPs engaged in direct diagnosis, treatment, and care of patients with COVID-19, OR 1.32 (95\% CI: 1.10, 1.59) [21] to 1.60 $(95 \%$ CI: $1.25,2.04)$ [20], frequency of contact with COVID-19 patients, OR 2.19 (95\% CI: $1.50,3.19)$ [23], working hours/week, OR 1.23 (95\% CI: 0.93, 1.62) [23], lacking access to adequate personal protective equipment (PPE), OR 1.83 (95\% CI: 1.22, 2.74) [23], COVID-19 positive cases above 20,000 cases, OR 2.01 (95\%CI: 1.22, 3.31) [24], and knowledge-attitudespractices (KAP) factors such as concern of own, OR 4.48 (95\% CI: $2.38,8.42)$ and negative coping style, OR 5.40 (95\% CI: 2.54, 11.46). Other risk factors reported by Zhu et al. [21] were education level of master's degree or higher, OR 1.55 (95\% CI: 1.16, 2.07), nurse occupation, OR 2.24 (95\% CI: 1.61, 3.12), medical technician, OR 1.57 (95\% CI: 1.12, 2.21), concomitant chronic diseases, OR 1.51 (95\% CI: 1.27, 1.80) or mental disorder, OR 3.27 (95\% CI: 1.77, 6.05), social status such as living with family members, OR 1.18 (95\% CI: $1.01,1.38$ ), family members or relatives suspected or confirmed COVID-19 case, OR 1.23 (95\%CI: 1.02, 1.48), and parental status of two or more children, OR 1.56 (95\% CI: $1.22,1.99)$. Chew et al. [3] found a bidirectional positive association between physical symptoms and PTSD, OR 2.70 (95\% CI: 1.40, 5.24) and between PTSD and physical symptoms, OR 2.20 (95\% CI: 1.12, 4.35).

Participants from outside Hubei province were associated with a lower risk of experiencing symptoms of PTSD compared with those in Wuhan, OR 0.62 (95\% CI: 0.43, 0.88) [20]. Nie et al. [22] found that positive knowledge-attitudes-practices (KAP) and coping style could offer a protective element, OR 0.38 (95\%CI: 0.22, 0.67).

\subsection{Prevalence and Determinants of Long-Term PTSD Symptoms}

Wu et al. [25] reported a prevalence of $10 \%$ for persistent PTSD symptoms among HCPs 3 years post SARS-2003 pandemic. They found that the following factors were associated significantly with higher risk of experiencing chronic PTSD symptoms (delayed and /or persistent 3 years after the pandemic was over): being in quarantine during the outbreak, OR 3.47 (95\% CI: 1.9, 6.2), age below 35 years old, OR 5.08 (95\% CI: 1.5, 17.7) or 36-50 years old, OR 4.54 (95\% CI: 1.3, 15.6), history of high work exposure, OR 3.11 (95\% CI: $1.8,5.5)$, and relative or friend got SARS, OR 3.74 (95\% CI: 1.8, 7.6). 


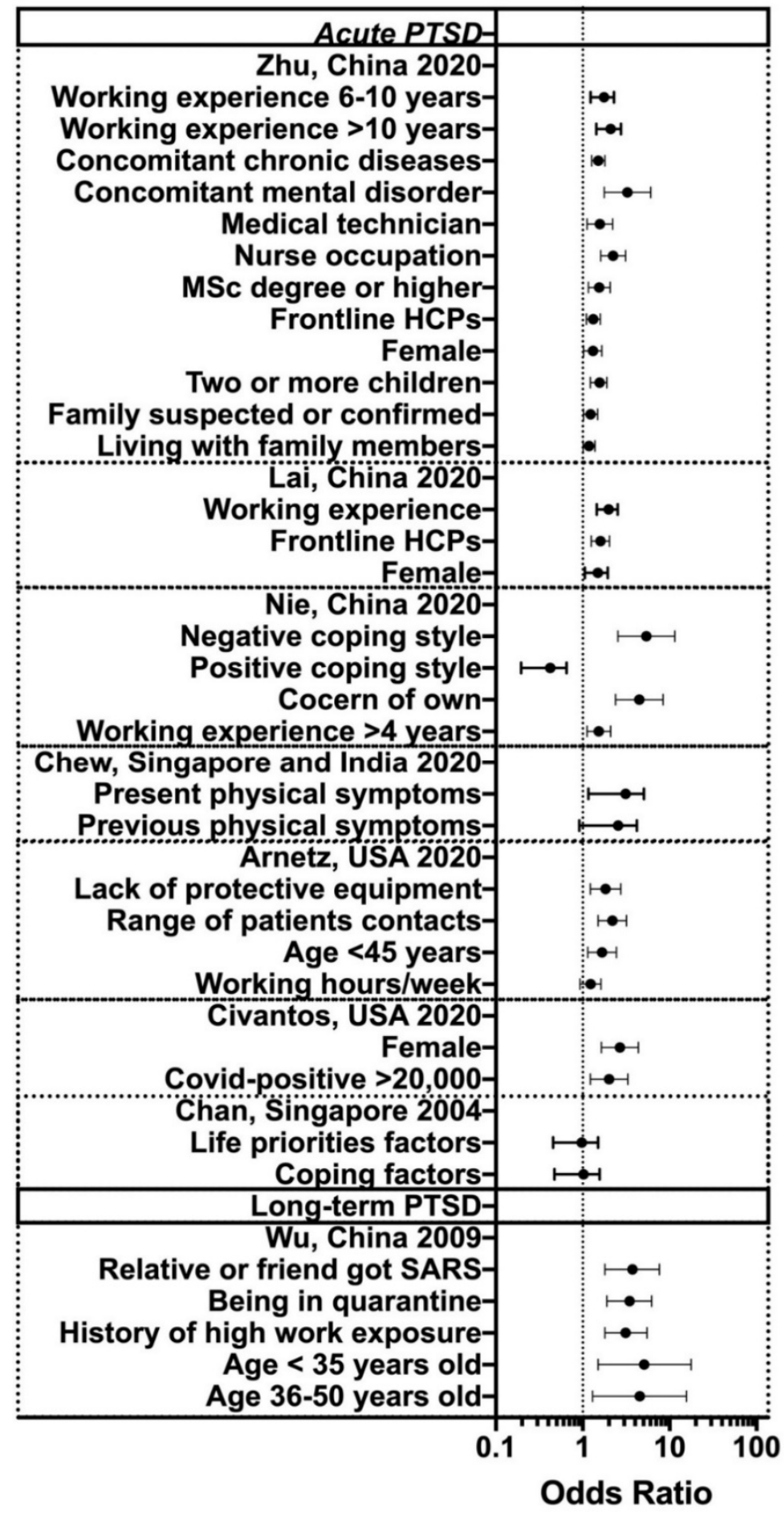

Figure 2. Determinants of acute and long-term PTSD.

\section{Discussion}

In this systematic review and meta-analysis, results were pooled from eight real-world observational studies that reported the prevalence of PTSD (frequency, \%) and associated risk factors (adjusted OR) on healthcare professionals (HCPS) during pandemics SARS CoV-2 and SARS CoV-1. These studies mostly addressed clinically significant PTSD in the acute phase during and immediately following a pandemic, while only one study addressed long-term PTSD. As evidenced by the data collected in this review, PTSD symptoms showed high prevalence variations ranging from 3.4\% [3] to 71.5\% [20] among HCPs. Determinants of immediate PTSD were reported for the CoV-2 pandemic, while those for long-term PTDS were reported for the CoV-1 pandemic.

While very limited data on the course of clinically important PTSD were available, our findings can be considered broadly consistent with the results of two meaningful pandemic meta-analyses on HCPs' mental health and pandemics [27,28]. While Pappa et al. studied 
the prevalence of depression, anxiety, and insomnia among HCPs during the COVID-19 outbreak [27], Allan et al. investigated the prevalence of common and stress-related mental health disorders in healthcare workers based in pandemic-affected hospitals [28]. Compared to Allan et al.'s meta-analysis [28], we limited our results to the SARS studies reporting odds ratios, while others did not [29-34] or had too small a sample size for regression analysis [35,36].

A series of early intervention trials aimed at individuals who were seen to be at high risk of PTSD development were prompted by a diagnosis of acute stress disorder [37]. Delayed-onset PTSD is defined as PTSD that develops at least 6 months after exposure to trauma, with cases of PTSD reportedly commencing years after the trauma occurrence [38]. Importantly, diagnosis during the acute phase after trauma is not intended to predict subsequent PTSD, but rather to describe people with elevated distress in the initial month who may benefit from mental health services [39]. No linear association could be identified between the severity of acute PTSD and the severity of delayed PTSD onset [40].

\subsection{Prevalence of PTSD}

In China, the highest prevalence reported was 71.5\% [20] for acute PTSD symptoms among HCPs, while the lowest prevalence was $25.1 \%$ [22]. A possible explanation for the variation is the data collection period, as Lai et al. collected data from 29 January to 3 February 2020, i.e., during the initiation and acceleration phase of the COVID-19 outbreak curve and complete lockdown of Wuhan city, Hubei province, while Nie et al.'s data collection period was 3-10 February 2020 in Guangdong province, which was considered less affected by COVID-19 compared to Wuhan city, Hubei province [41-44].

In the USA, Civantos et al. [24] reported twofold higher prevalence of acute PTSD symptoms of $60.2 \%$, compared to Arnetz et al. [23] (26.5\%). One possible explanation for this discrepancy is the different use of self-reported tools used to ascertain PTSD. Civantos et al. [24] used the 15-item revised impact event scale (IES-R15) to detect symptoms over past 7 days among nurses (estimated response rate: $4 \%$ ) during the month of May 2020, while Arnetz et al. [23] used the six-items Post-Traumatic Checklist (PCL-6) to detect PTSD symptoms in the past 4 weeks among otolaryngology physician (estimated repose rate: $10.2 \%$ ) during the month of April.

The lowest prevalence of PTSD symptoms was reported in Singapore at 3\% and $4 \%[3,26]$ and India at $3.4 \%$ [3]. There is a high variability in the association of traumatic events with PTSD, as it is not necessary for everyone exposed to a potentially traumatic event to develop a disorder [45].

Wu et al. [25] reported a prevalence of $10 \%$ for persistent PTSD symptoms among HCPs 3 years post SARS-2003 pandemic. Similar findings were reported by Maunder et al. [30], suggesting that impact of SARS can persist 1 to 2 years after the outbreak among HCPs compared with colleagues in settings that did not treat SARS patients.

\subsection{Determinants of PTDS}

Included studies in this review investigated varied determinants or risk factors associated with high prevalence of PTSD symptoms among HCPs. Gender, age, experience (working years), and degree of exposure (level, load, and amount of close contact or care) variables commonly showed significant association with high PTSD symptoms among different studies in different countries on different continents. As PTSD determinants, personal characteristics, conditions, and energies are resources of both instrumental and symbolic usefulness. Personal characteristics such as a positive attitude, view of events as predictable, and the ability to deal with stress are ways to help protect against stress [46]. Personal conditions, such as job training and seniority, are resources that are valued and sought after by an individual [47]. Any provided condition may be a resource for one person but may be harmful for another [48]. Personal energy resources include time, money, and expertise. This type of resource is useful, since it can be used to obtain additional resources $[48,49]$. 


\section{Strengths and Limitations of the Study}

This review had several strengths. It included research on two pandemics in Asia and North America, including investigation of PTSD symptoms with further regression analyses of possible risk factors. It demonstrated and highlighted the immediate and delayed traumatic effects of two pandemics in various settings and subpopulations of HCPs. This systematic review, therefore, provides valuable information and may serve as a guide for policymakers to establish and provide guidance on immediate and long-term traumatic stress among HCPs.

This review had several limitations. The search was limited to English language only and only those published in peer-reviewed journals; thus, it could be prone to publication bias. The studies were all cross-sectional studies, with a short follow-up period; therefore, the studies could not prove causality. Since all studies were self-reported with different cutoff scales and different versions of the Impact Event Scale (IES), and since no study utilized standardized clinical interviews for diagnosis as a confirmation tool, it is unknown whether the presence of an actual disorder existed, which could have led to misclassification and recall biases. However, in such pandemic situations, this was not a feasible way to conduct studies as direct contact was restricted. Nevertheless, it could be possible to investigate delayed or persistent PTSD once the pandemic is over. Furthermore, the majority of studies were heterogeneous in their operational assessment of exposure and used population screening scales to assess PTSD determinants with different cutoff scores. Therefore, summarizing the prevalence of PTSD and its determinants among HCPs with a single-point estimate was difficult, and reported findings need to be interpreted with cautions.

When used alone, the OR, which remains a representation of the power of association between the risk factor and the onset of PTSD, offers little detail. Meta-analyses represent an accumulation of knowledge that can often lead to meanings that do not address the clinical validity issue and leave the decision to be made in confusion [50]. This approach must then be used with experience and moderation and, where possible, should be supplemented by additional research illustrating the clinical validity of the meanings acquired.

\section{Conclusions}

A comprehensive understanding of the prevalence and determinants of immediate or long-term PTSD related to pandemics for healthcare workers may enhance its prevention, diagnosis, and management. Working experience, occupation, protective conditions, concomitant chronic diseases, present physical symptoms, mental disorder, negative coping style, and family-related factors were identified as determinants of an immediate PTSD. Exposure to SARS, being in quarantine, high work exposure, and age were reported as determinants of a long-term PTSD. The risk of immediate or long-term PTSD can be decreased on the basis of identifiable risk factors.

Studies are yet to investigate the long-term consequences of PTSD after a CoV-2 pandemic over longer periods of time. Rigorous studies evaluating the prevalence of PTSD and its related risk factors (adjusted OR) for the CoV-2 pandemic are envisaged. While strategies to tackle immediate PTSD are key, strategies for long-term PTSD must not be ignored.

Author Contributions: Study conceptualization and design, M.a.D., M.a.Q., and H.a.T.; analysis and interpretation of the data, B.a.F., M.D., M.a.A., M.a.M., A.a.A., M.a.K., M.D., M.a.Q., H.a.T., O.C.B., and L.A.C.; drafting of manuscript, H.a.T., O.C.B., and L.A.C.; critical revision, B.a.F., M.D., M.a.A., M.a.M., A.a.A., M.a.K., M.D., M.a.Q., H.a.T., O.C.B., and L.A.C. All authors have read and agreed to the published version of the manuscript.

Funding: This publication is based upon work supported by the Khalifa University of Science and Technology under Award No. FSU-2020-33.

Institutional Review Board Statement: Not applicable. 
Informed Consent Statement: Not applicable.

Data Availability Statement: Data sharing not applicable. No new data were created or analyzed in this study. Data sharing is not applicable to this article.

Acknowledgments: We gratefully acknowledge Afrah al Tunaiji (head of family medicine residency program, Zayed Military Hospital Abu Dhabi, United Arab Emirates), Asma al Humeri (deputy of family medicine residency program, Zayed Military Hospital, Abu Dhabi, United Arab Emirates), and Farah al Zaabi (head of medical education department, Zayed Military Hospital, Abu Dhabi, United Arab Emirates) for their leadership on the medical residency program and providing support for the residents in completing the systematic review as part of their residency program.

Conflicts of Interest: The authors do not declare any commercial or financial conflicts of interest.

\section{References}

1. Dutheil, F.; Mondillon, L.; Navel, V. PTSD as the second tsunami of the SARS-Cov-2 pandemic. Psychol. Med. 2020, 1-2. [CrossRef] [PubMed]

2. Benfante, A.; Di Tella, M.; Romeo, A.; Castelli, L. Traumatic Stress in Healthcare Workers During COVID-19 Pandemic: A Review of the Immediate Impact. Front. Psychol. 2020, 11, 569935. [CrossRef]

3. Chew, N.W.S.; Lee, G.K.H.; Tan, B.Y.Q.; Jing, M.; Goh, Y.; Ngiam, N.J.H.; Yeo, L.L.L.; Ahmad, A.; Ahmed Khan, F.; Napolean Shanmugam, G.; et al. A multinational, multicentre study on the psychological outcomes and associated physical symptoms amongst healthcare workers during COVID-19 outbreak. Brain Behav. Immun. 2020, 88, 559-565. [CrossRef] [PubMed]

4. Wilder-Smith, A.; Chiew, C.J.; Lee, V.J. Can we contain the COVID-19 outbreak with the same measures as for SARS? Lancet Infect. Dis. 2020, 20, e102-e107. [CrossRef]

5. Pan, F.; Ye, T.; Sun, P.; Gui, S.; Liang, B.; Li, L.; Zheng, D.; Wang, J.; Hesketh, R.L.; Yang, L.; et al. Time Course of Lung Changes at Chest CT during Recovery from Coronavirus Disease 2019 (COVID-19). Radiology 2020, 295, 715-721. [CrossRef] [PubMed]

6. Mak, I.W.C.; Chu, C.M.; Pan, P.C.; Yiu, M.G.C.; Chan, V.L. Long-term psychiatric morbidities among SARS survivors. Gen. Hosp. Psychiatry 2009, 31, 318-326. [CrossRef]

7. Grace, S.L.; Hershenfield, K.; Robertson, E.; Stewart, D.E. The occupational and psychosocial impact of SARS on academic physicians in three affected hospitals. Psychosomatics 2005, 46, 385-391. [CrossRef]

8. Chou, R.; Dana, T.; Buckley, D.I.; Selph, S.; Fu, R.; Totten, A.M. Epidemiology of and risk factors for coronavirus infection in health care workers: A living rapid review. Ann. Intern. Med. 2020, 173, 120-136. [CrossRef]

9. Denckla, C.A.; Gelaye, B.; Orlinsky, L.; Koenen, K.C. REACH for mental health in the COVID19 pandemic: An urgent call for public health action. Eur. J. Psychotraumatol. 2020, 11, 1762995. [CrossRef]

10. Koolhaas, J.M.; Bartolomucci, A.; Buwalda, B.; de Boer, S.F.; Flügge, G.; Korte, S.M.; Meerlo, P.; Murison, R.; Olivier, B.; Palanza, P.; et al. Stress revisited: A critical evaluation of the stress concept. Neurosci. Biobehav. Rev. 2011, 35, 1291-1301. [CrossRef]

11. Morens, D.M.; Daszak, P.; Taubenberger, J.K. Escaping Pandora's Box-Another Novel Coronavirus. N. Engl. J. Med. 2020, 382, 1293-1295. [CrossRef] [PubMed]

12. Shaukat, N.; Ali, D.M.; Razzak, J. Physical and mental health impacts of COVID-19 on healthcare workers: A scoping review. Int. J. Emerg. Med. 2020, 13, 40. [CrossRef] [PubMed]

13. Neria, Y.; Nandi, A.; Galea, S. Post-traumatic stress disorder following disasters: A systematic review. Psychol. Med. 2008, 38, 467-480. [CrossRef] [PubMed]

14. Krishnamoorthy, Y.; Nagarajan, R.; Saya, G.K.; Menon, V. Prevalence of psychological morbidities among general population, healthcare workers and COVID-19 patients amidst the COVID-19 pandemic: A systematic review and meta-analysis. Psychiatry Res. 2020, 293, 113382. [CrossRef]

15. Salazar de Pablo, G.; Vaquerizo-Serrano, J.; Catalan, A.; Arango, C.; Moreno, C.; Ferre, F.; Shin, J.I.; Sullivan, S.; Brondino, N.; Solmi, M.; et al. Impact of coronavirus syndromes on physical and mental health of health care workers: Systematic review and meta-analysis. J. Affect. Disord. 2020, 275, 48-57. [CrossRef] [PubMed]

16. Sheraton, M.; Deo, N.; Dutt, T.; Surani, S.; Hall-Flavin, D.; Kashyap, R. Psychological effects of the COVID 19 pandemic on healthcare workers globally: A systematic review. Psychiatry Res. 2020, 292, 113360. [CrossRef]

17. Da Silva, F.C.T.; Neto, M.L.R. Psychiatric symptomatology associated with depression, anxiety, distress, and insomnia in health professionals working in patients affected by COVID-19: A systematic review with meta-analysis. Prog. Neuropsychopharmacol. Biol. Psychiatry 2021, 104, 110057. [CrossRef]

18. Moher, D.; Liberati, A.; Tetzlaff, J.; Altman, D.G.; PRISMA Group. Preferred reporting items for systematic reviews and meta-analyses: The PRISMA statement. BMJ 2009, 339, b2535. [CrossRef] [PubMed]

19. Moola, S.; Munn, Z.; Sears, K.; Sfetcu, R.; Currie, M.; Lisy, K.; Tufanaru, C.; Qureshi, R.; Mattis, P.; Mu, P. Conducting systematic reviews of association (etiology): The Joanna Briggs Institute's approach. Int. J. Evid. Based. Healthc. 2015, 13, 163-169. [CrossRef]

20. Lai, J.; Ma, S.; Wang, Y.; Cai, Z.; Hu, J.; Wei, N.; Wu, J.; Du, H.; Chen, T.; Li, R.; et al. Factors associated with mental health outcomes among health care workers exposed to coronavirus disease. JAMA Netw. Open 2020, 3, e203976. 
21. Zhu, Z.; Xu, S.; Wang, H.; Liu, Z.; Wu, J.; Li, G.; Miao, J.; Zhang, C.; Yang, Y.; Sun, W.; et al. COVID-19 in Wuhan: Sociodemographic characteristics and hospital support measures associated with the immediate psychological impact on healthcare workers. EClinicalMedicine 2020, 24, 100443. [CrossRef] [PubMed]

22. Nie, A.; Su, X.; Zhang, S.; Guan, W.; Li, J. Psychological impact of COVID-19 outbreak on frontline nurses: A cross-sectional survey study. J. Clin. Nurs. 2020, 29, 4217-4226. [CrossRef]

23. Arnetz, J.E.; Goetz, C.M.; Sudan, S.; Arble, E.; Janisse, J.; Arnetz, B.B. Personal Protective Equipment and Mental Health Symptoms Among Nurses During the COVID-19 Pandemic. J. Occup. Environ. Med. 2020, 62, 892-897. [CrossRef] [PubMed]

24. Civantos, A.M.; Byrnes, Y.; Chang, C.; Prasad, A.; Chorath, K.; Poonia, S.K.; Jenks, C.M.; Bur, A.M.; Thakkar, P.; Graboyes, E.M.; et al. Mental health among otolaryngology resident and attending physicians during the COVID-19 pandemic: National study. Head Neck 2020, 42, 1597-1609. [CrossRef] [PubMed]

25. Wu, P.; Fang, Y.; Guan, Z.; Fan, B.; Kong, J.; Yao, Z.; Liu, X.; Fuller, C.J.; Susser, E.; Lu, J.; et al. The psychological impact of the SARS epidemic on hospital employees in China: Exposure, risk perception, and altruistic acceptance of risk. Can. J. Psychiatry 2009, 54, 302-311. [CrossRef] [PubMed]

26. Chan, A.O.M.; Huak, C.Y. Psychological impact of the 2003 severe acute respiratory syndrome outbreak on health care workers in a medium size regional general hospital in Singapore. Occup. Med. 2004, 54, 190-196. [CrossRef]

27. Pappa, S.; Ntella, V.; Giannakas, T.; Giannakoulis, V.G.; Papoutsi, E.; Katsaounou, P. Prevalence of depression, anxiety, and insomnia among healthcare workers during the COVID-19 pandemic: A systematic review and meta-analysis. Brain Behav. Immun. 2020, 88, 901-907. [CrossRef]

28. Allan, S.M.; Bealey, R.; Birch, J.; Cushing, T.; Parke, S.; Sergi, G.; Bloomfield, M.; Meiser-Stedman, R. The prevalence of common and stress-related mental health disorders in healthcare workers based in pandemic-affected hospitals: A rapid systematic review and meta-analysis. Eur. J. Psychotraumatol. 2020, 11, 1810903. [CrossRef] [PubMed]

29. Lin, C.Y.; Peng, Y.C.; Wu, Y.H.; Chang, J.; Chan, C.H.; Yang, D.Y. The psychological effect of severe acute respiratory syndrome on emergency department staff. Emerg. Med. J. 2007, 24, 12-17. [CrossRef] [PubMed]

30. Maunder, R.G.; Lancee, W.J.; Balderson, K.E.; Bennett, J.P.; Borgundvaag, B.; Evans, S.; Fernandes, C.M.B.; Goldbloom, D.S.; Gupta, M.; Hunter, J.J.; et al. Long-term psychological and occupational effects of providing hospital healthcare during SARS outbreak. Emerg. Infect. Dis. 2006, 12, 1924-1932. [CrossRef]

31. Maunder, R.G.; Lancee, W.J.; Rourke, S.; Hunter, J.J.; Goldbloom, D.; Balderson, K.; Petryshen, P.; Steinberg, R.; Wasylenki, D.; Koh, D.; et al. Factors associated with the psychological impact of severe acute respiratory syndrome on nurses and other hospital workers in Toronto. Psychosom. Med. 2004, 66, 938-942. [CrossRef]

32. Phua, D.H.; Tang, H.K.; Tham, K.Y. Coping responses of emergency physicians and nurses to the 2003 severe acute respiratory syndrome outbreak. Acad. Emerg. Med. 2005, 12, 322-328. [CrossRef]

33. Chong, M.-Y.; Wang, W.-C.; Hsieh, W.-C.; Lee, C.-Y.; Chiu, N.-M.; Yeh, W.-C.; Huang, O.-L.; Wen, J.-K.; Chen, C.-L. Psychological impact of severe acute respiratory syndrome on health workers in a tertiary hospital. Br. J. Psychiatry 2004, 185, 127-133. [CrossRef]

34. Chen, C.-S.; Wu, H.-Y.; Yang, P.; Yen, C.-F. Psychological distress of nurses in Taiwan who worked during the outbreak of SARS. Psychiatr. Serv. 2005, 56, 76-79. [CrossRef]

35. Sin, S.S.; Huak, C.Y. Psychological impact of the SARS outbreak on a Singaporean rehabilitation department. Int. J. Ther. Rehabil. 2004, 11, 417-424. [CrossRef]

36. Su, T.-P.; Lien, T.-C.; Yang, C.-Y.; Su, Y.L.; Wang, J.-H.; Tsai, S.-L.; Yin, J.-C. Prevalence of psychiatric morbidity and psychological adaptation of the nurses in a structured SARS caring unit during outbreak: A prospective and periodic assessment study in Taiwan. J. Psychiatr. Res. 2007, 41, 119-130. [CrossRef]

37. Roberts, N.P.; Kitchiner, N.J.; Kenardy, J.; Lewis, C.E.; Bisson, J.I. Early psychological intervention following recent trauma: A systematic review and meta-analysis. Eur. J. Psychotraumatol. 2019, 10, 1695486. [CrossRef] [PubMed]

38. Ruzich, M.J.; Looi, J.C.L.; Robertson, M.D. Delayed onset of posttraumatic stress disorder among male combat veterans: A case series. Am. J. Geriatr. Psychiatry 2005, 13, 424-427. [CrossRef]

39. Bryant, R.A.; Friedman, M.J.; Spiegel, D.; Ursano, R.; Strain, J. A review of acute stress disorder in DSM-Depress. Anxiety 2011, 28, 802-817. [PubMed]

40. Bryant, R.A. Post-traumatic stress disorder: A state-of-the-art review of evidence and challenges. World Psychiatry 2019, 18, 259-269. [CrossRef] [PubMed]

41. Lin, Q.; Zhao, S.; Gao, D.; Lou, Y.; Yang, S.; Musa, S.S.; Wang, M.H.; Cai, Y.; Wang, W.; Yang, L.; et al. A conceptual model for the coronavirus disease 2019 (COVID-19) outbreak in Wuhan, China with individual reaction and governmental action. Int. J. Infect. Dis. 2020, 93, 211-216. [CrossRef] [PubMed]

42. Wang, H.; Wang, Z.; Dong, Y.; Chang, R.; Xu, C.; Yu, X.; Zhang, S.; Tsamlag, L.; Shang, M.; Huang, J.; et al. Phase-adjusted estimation of the number of Coronavirus Disease 2019 cases in Wuhan, China. Cell Discov. 2020, 6, 10. [CrossRef] [PubMed]

43. Zhang, J.; Litvinova, M.; Wang, W.; Wang, Y.; Deng, X.; Chen, X.; Li, M.; Zheng, W.; Yi, L.; Chen, X.; et al. Evolving epidemiology and transmission dynamics of coronavirus disease 2019 outside Hubei province, China: A descriptive and modelling study. Lancet Infect. Dis. 2020, 20, 793-802. [CrossRef] 
44. Kraemer, M.U.G.; Yang, C.-H.; Gutierrez, B.; Wu, C.-H.; Klein, B.; Pigott, D.M.; Open COVID-19 Data Working Group; du Plessis, L.; Faria, N.R.; Li, R.; et al. The effect of human mobility and control measures on the COVID-19 epidemic in China. Science 2020, 368, 493-497. [CrossRef]

45. Kessler, R.C.; Sonnega, A.; Bromet, E.; Hughes, M.; Nelson, C.B. Posttraumatic stress disorder in the National Comorbidity Survey. Arch. Gen. Psychiatry 1995, 52, 1048-1060. [CrossRef]

46. Jones, H.; Dorahy, M.J.; Britt, E.; Rowlands, A.; Renouf, C.; Carter, J.D.; Hanna, D. Predictors of posttraumatic stress symptom trajectories following the fatal 2011 Christchurch, New Zealand earthquake. J. Trauma. Stress 2019, 32, 206-214. [CrossRef]

47. Shin, M.G.; Kim, Y.-K.; Kim, S.-Y.; Kang, D.M. Relationship Between Job Training and Subjective Well-being in Accordance with Work Creativity, Task Variety, and Occupation. Saf. Health Work 2020, 11, 466-478. [CrossRef]

48. Hobfoll, S.E. Conservation of resources. A new attempt at conceptualizing stress. Am. Psychol. 1989, 44, 513-524. [CrossRef]

49. Maguen, S.; Griffin, B.J.; Copeland, L.A.; Perkins, D.F.; Richardson, C.B.; Finley, E.P.; Vogt, D. Trajectories of functioning in a population-based sample of veterans: Contributions of moral injury, PTSD, and depression. Psychol. Med. 2020, 1-10. [CrossRef]

50. Bloch, F. Literature review and meta-analysis of risk factors for delayed post-traumatic stress disorder in older adults after a fall. Int. J. Geriatr. Psychiatry 2017, 32, 136-140. [CrossRef] 